\title{
Higher pharmaceutical public expenditure after direct price control: improved access or induced demand? The Colombian case
}

\author{
Sergio I. Prada ${ }^{1}$, Victoria E. Soto ${ }^{1}$, Tatiana S. Andia ${ }^{2 *}$, Claudia P. Vaca ${ }^{3}$, Álvaro A. Morales ${ }^{2}$, Sergio R. Márquez ${ }^{4}$ \\ and Alejandro Gaviria ${ }^{4}$
}

\begin{abstract}
Background: High pharmaceutical expenditure is one of the main concerns for policymakers worldwide. In Colombia, a middle-income country, outpatient prescription represents over $10 \%$ of total health expenditure in the mandatory benefits package (POS), and close to $90 \%$ in the complementary government fund (No POS). In order to control expenditure, since 2011, the Ministry of Health introduced price caps on inpatient drugs reimbursements by active ingredient. By 2013, more than 400 different products, covering $80 \%$ of public pharmaceutical expenditure were controlled. This paper investigates the effects of the Colombian policy efforts to control expenditure by controlling prices.

Methods: Using SISMED data, the official database for prices and quantities sold in the domestic market, we estimate a Laspeyres price index for 90 relevant markets in the period 2011-2015, and, then, we estimate real pharmaceutical expenditure.

Results: Results show that, after direct price controls were enacted, price inflation decreased almost - 43\%, but real pharmaceutical expenditure almost doubled due mainly to an increase in units sold. Such disproportionate increase in units sold maybe attributable to better access to drugs due to lower prices, and/or to an increase in marketing efforts by the pharmaceutical industry to maintain profits.
\end{abstract}

Conclusions: We conclude that pricing interventions should be implemented along with a strong market monitoring to prevent market distortions such as inappropriate and unnecessary drug use.

Keywords: Pharmaceutical price control, Public expenditure, Developing countries, Middle income

\section{Background}

Colombia is the first country in Latin-American to achieve nearly Universal Health Coverage, offering a benefit package (POS, henceforth per the Spanish acronym) to all citizens regardless of whether they contribute or not [1]. The package includes services and technologies for health promotion, prevention, diagnosis, treatment and rehabilitation services for all levels of complexity [2]. In addition, all citizens have access to technologies and social services excluded from POS (No-POS, henceforth

\footnotetext{
*Correspondence: tandia@uniandes.edu.co

${ }^{2}$ Facultad de Ciencias Sociales, Universidad de los Andes, Carrera 1 \#

18A-12, Bogotá, Colombia

Full list of author information is available at the end of the article
}

per the Spanish acronym) through two mechanisms: (i) by requesting that a scientific technical committee studies the pertinence of using a new technology that supposedly it's better than those included in the benefit package (POS), (ii) by a judicial mandate that orders the State to pay directly for the new technology in protection to the individual's constitutional right to health.

The former mechanism was abolished in early 2017. Currently prescribers must fill in an electronic form in order to get direct approval by the government. Under any mechanism, new and current technologies and services, not included in the package of benefits (POS), are paid for by the government under a reimbursement scheme. Insurers pay providers and then request reimbursement to a central fund, which audits and decides 
whether to reimburse totally or partially according to rules defined by the government.

Hence, rising pharmaceutical expenditure is a great concern for health authorities, given both its importance in the total health expenditure and its rapid growth [3]. In 2008, for example, it represented $10.2 \%$ of POS expenditure [4] and close to $90 \%$ of No-POS expenditure [5]. While POS expenditure has been stable and even decreasing [4], No-POS expenditure is seriously threatening the health system's financial stability $[5,6]$. In 2004, reimbursements paid were a mere US 34 million, in 2007 US $207 \mathrm{~m}$, and in 2010 reached US $828 \mathrm{~m}$ [7, 8]. Since 2010 the amount paid by the government remains around US $840 \mathrm{~m}$ due to budgetary constraints, but the amount claimed by insurers is about $25 \%$ more. The concentration of this pharmaceutical expenditure is also impressive, in 2011, only 38 drugs accounted for $88 \%$ of these reimbursements [5].

By legal requirement, POS benefits must be updated every other year, mostly by including new technologies [9]. However, the new inclusions have not halted the NoPOS reimbursement requests. A good reason for that is that No-POS expenditure is mainly for new technologies for high-cost diagnosis such as Cancer, Arthritis, HIV, rare diseases and organ transplants. There is also considerable No-POS expenditure on brand-name drugs excluded from POS and on social services such as diapers for older adults [6]. In addition, during the previous decade, Colombia had the highest pharmaceutical prices in Latin America due to the lack of pharmaceutical regulatory framework [10]. Reimbursement prices for No-POS drugs were comparatively higher in Colombia than that in other country in the region [10].

In the context of this growing pressure to control NoPOS pharmaceutical expenditure, the government enacted a comprehensive pharmaceutical policy that includes various tools depending on the policy objectives. There are two different institutions involved in pharmaceutical price regulation. The Comisión Nacional de Precios de Medicamentos y Dispositivos Médicos (CNPMDM), ${ }^{1}$ an inter-ministerial commission, oversees the design of the methodology whereby drug prices are to be regulated. The other institution is the Ministry of Health $(\mathrm{MOH})$, responsible for implementing price regulation.

Two different mechanisms were used initially by the $\mathrm{MoH}$ and the CNPMDM to regulate the pharmaceutical

\footnotetext{
${ }^{1}$ The CNPMDM is an inter-ministerial commission created for regulating pharmaceutical and medical device prices. The commission is formed by a representative of the President, the Minister of Trade and the Minister of Health and it relies on policy proposals developed by a technical advisory group based at the ministry of health.
}

market: price caps on No-POS drugs to be reimbursed by the government, and the introduction of an external price referencing (ERP) system for selected therapeutical groups.

Price caps for No-POS drugs were mainly used between 2010 and 2012. The CNPMDM established a maximum price for No-POS drugs [8] at which the government reimburses the health insurance company. The cap was calculated as the median wholesale price less a fixed percentage (20\%). In 2011, around 80 commercial drugs were regulated using this methodology [11].

In 2013, the CNPMDM introduced ERP. If the price of a selected drug was higher in Colombia than that of the 25 percentile within a set of 17 countries where the drug was already commercialized, the price was regulated setting the price to the 25 percentile [8]. A drug was eligible for regulation when: (1) it was considered of public interest for public health reasons or because it had a high financial impact and (2) it had no therapeutic substitutes or it had a high market concentration when compared to other drugs in the same therapeutic group. Both POS and No-POS drugs could be regulated and the regulation applied to market prices, and not only to government reimbursement prices like the previous cap prices [12].

Overall, the CNPMDM regulated 79 ATC using ERP between 2013 and 2014 [13-16]. By 2013, the ERP scheme included more than 3000 products, covering $80 \%$ of public drug expenditure [17].

In addition to direct control pricing, the government put into practice another measure in order to control health expenditure and increase access. By including in the benefit package (POS) some of the highest reimbursed No-POS drugs, the government expected that payers would be able to bargain prices down. Between 2011 and 2015 the benefit package was updated twice, in 2011 and 2013.

In this context, the aim of this study is to investigate the effects of the Colombian policy efforts to contain pharmaceutical expenditure by controlling prices. Numerous studies have analyzed the types of ERP and their impacts on outcomes in industrialized countries [18-21], but there are scant analyses of similar issues in middle income countries such as Colombia [22, 23]. Similarly, despite its prominent application, only few studies have analyzed the impact of EPR on outcomes [24].

The paper thus contributes to the existing literature by providing evidence of ERP application in a middleincome country and by estimating real pharmaceutical expenditure effects based on a Laspeyres price index for 90 relevant markets in the period 2011-2015. Also, given that the increase or decrease in pharmaceutical expenditure is a result of the simultaneous variation in price and quantity [3], the paper decomposes pharmaceutical 
spending growth into price and quantity components, to better understand the direct and indirect effects of price regulation of pharmaceuticals in Colombia. The paper concludes with some general policy recommendations for low and middle-income countries.

\section{Study data and methods \\ Data}

Data on prices and quantities sold comes from Sistema de Información de Precios de Medicamentos (SISMED). Anyone selling pharmaceuticals (i.e., the pharmaceutical industry, wholesalers, health providers and public facilities) must report prices and quantities sold by type of market. SISMED contains monthly data on purchased price, sales price, sold units, ATC, name drug-brand, pharmaceutical form, minimum units of concentration (UMC), type of market and type of seller (laboratory, wholesaler, insurer and provider). SISMED distinguishes two distinct markets [18]: institutional and private. The institutional market involves public resources and agglutinates public and private entities. The private market is the OTC market. Governmental price controls apply only to the institutional market.

\section{Methods}

For this study, the top 90 drugs by sales in 2015 at the active ingredient level were selected. Criteria for selection were whether the market was regulated, whether there were substitutes, and whether the drug in question had been included in POS updates. Data on prices and quantities were available monthly since 2011 through 2015 (see Table 1). To estimate real pharmaceutical expenditure, we computed a monthly price index for the period 2011-2015. There are several types of price (inflation) indexes. The three most common are Laspeyres, Paasche and Fisher. A Laspeyres price index is calculated as an arithmetic mean of a fixed bundle of goods and services. A Paasche index is a ratio that compares the total cost of a bundle of goods and services valued at current prices with the value of that same bundle at base-period prices. A Fisher index is the geometric mean of a Laspeyres and a Paasche index (that prices a fixed bundle of current period goods and services). Due to reporting missing values on quantities in several months [3], we decided to use a Laspeyres price index:

$$
P I_{L}=\frac{\sum_{i=1}^{I} P_{t, i} * Q_{t-1, i}}{\sum_{i=1}^{I} P_{t-1, i} * Q_{t-1, i}}
$$

where $P_{t, i}$ is the price of active ingredient $i$ in month $t$ of the year and $P_{t-1, i}$ is the price of active ingredient $i$ in base year (September 2011). Prices and quantities were standardized to a common unit of concentration.
For each ATC, the common unit of concentration is the weight unit in which the concentration of the active ingredient is expressed. For example, Atorvastatin is sold in concentrations ranging from 10 to $40 \mathrm{mg}$, then, to make comparison possible among the different commercial presentations with this active ingredient, all prices and units sold by each ATC must be in a common unit. To achieve this, the concentration is multiplied by the total amount of minimal dispensed units (in this case, tablets) that are sold in each one of the commercial presentations, which gives the total amount of active ingredient (given in the common unit of concentration, in this case milligrams) per product.

The total units sold per commercial presentation are then multiplied by the respective total amount of active ingredient. The sum of these units is equal to the total amount of active ingredient sold in a specific time frame (month).

On the other hand, the market price reported in SISMED for each of the commercial presentations is divided by the total amount of active ingredient, to obtain the price per common unit of concentration per presentation.

In addition, $P I_{L}$ was calculated by regulated and nonregulated ATC, and for the following therapeutical groups: immunosuppressant, insulins and oncology. Nominal sales were adjusted for inflation as measured by the Laspeyres price index to obtain the increase in real terms. The real value of expenditures, our proxy for quantities sold in the market, is thus obtained by removing the effect of price level changes from the nominal value of the time-series data.

All analyses were carried out in Colombian pesos. Figures were converted to US dollars using an exchange rate of 2976 COP/1 USD. It is important to note that the nominal exchange rate did not vary abruptly within the period 2011-2014 thus for pharmaceutical specialities that were imported prices do not reflect spurious exchange rate fluctuations. For 2015, although the exchange rate increased due to the oil price crisis, it did not affect our calculation because regulated prices were fixed in Colombian pesos and the formula used by the government included the average exchange rate of the year before. In sum, exchange rate fluctuations do not affect our price index calculation.

Laspeyres indexes hold previous period quantities fixed and may be biased because people may substitute away from drugs whose prices rise more rapidly. Accordingly, Laspeyres indexes tend to overstate inflation; however, such bias may be attenuated in Colombia because drug approvals are usually long and protracted. The administrative procedures can take up to 72 weeks. Also, the economic incentives work the other way 
Table 1 Molecules analysed

\begin{tabular}{|c|c|c|}
\hline ATC & ATC name & ATC regulated \\
\hline A10AB01 & INSULINA (HUMANA) & Non regulated \\
\hline $\mathrm{A} 10 \mathrm{AB} 04$ & INSULINA LISPRO & Regulated \\
\hline A10AB06 & INSULINA (HUMANA) & Regulated \\
\hline A10AC01 & INSULINA (HUMANA) & No regulated \\
\hline A10AD01 & INSULINA (HUMANA) & No regulated \\
\hline A10AD04 & INSULINA LISPRO & Regulated \\
\hline A10AE04 & INSULINA GLARGINA & Regulated \\
\hline B01AC04 & CLOPIDOGREL & Regulated \\
\hline B01AC05 & TICLOPIDINA & Non regulated \\
\hline B01AC06 & ACETILSALICILICO ACIDO & Regulated \\
\hline B01AC07 & DIPIRIDAMOL & Regulated \\
\hline B01AC09 & EPOPROSTENOL & Non regulated \\
\hline B01AC11 & ILOPROST & Regulated \\
\hline B01AC13 & $A B C I X I M A B$ & Non regulated \\
\hline B01AC17 & TIROFIBAN & Regulated \\
\hline B01AC22 & PRASUGREL & Regulated \\
\hline B01AC23 & CILOSTAZOL & Non regulated \\
\hline B02BD02 & COAGULACION FACTORES VIII & Regulated \\
\hline B02BD03 & $\begin{array}{l}\text { FACTOR VIII INHIBIDOR ACTIVADO } \\
\text { POR BYPASS }\end{array}$ & Regulated \\
\hline B02BD04 & COAGULACION FACTOR IX & Regulated \\
\hline B02BD06 & COAGULACION FACTORES VIII & Regulated \\
\hline B02BD07 & COAGULACION FACTOR XIII & Regulated \\
\hline C07AB02 & METOPROLOL & Regulated \\
\hline C07AB12 & NEBIVOLOL & Non regulated \\
\hline C07AG01 & LABETALOL & Regulated \\
\hline C07AG02 & CARVEDILOL & Regulated \\
\hline C10AA01 & SIMVASTATINA & Regulated \\
\hline C10AA02 & LOVASTATINA & Regulated \\
\hline C10AA03 & PRAVASTATINA & Regulated \\
\hline C10AA04 & FLUVASTATINA & Non regulated \\
\hline C10AA05 & ATORVASTATIN & Regulated \\
\hline $\begin{array}{r}\text { C10AA05// } \\
\text { C10AX09 }\end{array}$ & ATORVASTATIN//EZETIMIBE & Regulated \\
\hline C10AA07 & ROSUVASTATINA & Regulated \\
\hline G04CA01 & ALFUZOSINA & Non regulated \\
\hline G04CA02 & TAMSULOSINA & Non regulated \\
\hline G04CA03 & TERAZOSINA & Non regulated \\
\hline G04CB01 & FINASTERIDA & Non regulated \\
\hline $\mathrm{H} 01 \mathrm{AB} 01$ & TIROTROPINA & Regulated \\
\hline H01AC01 & SOMATROPINA & Regulated \\
\hline J01DH02 & MEROPENEM & Regulated \\
\hline J01DH03 & ERTAPENEM & Non regulated \\
\hline J01DH51 & IMIPENEM E INHIBIDOR DE ENZIMA & Regulated \\
\hline J07AL01 & $\begin{array}{l}\text { NEUMOCOCO ANTIGENOS } \\
\text { POLISACARIDOS PURIFICADOS }\end{array}$ & Regulated \\
\hline $\begin{array}{l}\text { J07AL01// } \\
\text { V08AA05 }\end{array}$ & $\begin{array}{l}\text { NEUMOCOCO ANTIGENOS } \\
\text { POLISACARIDOS PURIFICADOS// } \\
\text { EXTRANEAL }\end{array}$ & Regulated \\
\hline J07AL02 & $\begin{array}{l}\text { VACUNA CONJUGADA NEUMOCO- } \\
\text { CICA }\end{array}$ & Non regulated \\
\hline
\end{tabular}

Table 1 continued

\begin{tabular}{|c|c|c|}
\hline ATC & ATC name & ATC regulated \\
\hline L01BA01 & METROTEXATE & Regulated \\
\hline L01XC02 & RITUXIMAB & Regulated \\
\hline L01XC03 & TRASTUZUMAB & Regulated \\
\hline L01XC07 & BEVACIZUMAB & Regulated \\
\hline L01XE01 & IMATINIB & Regulated \\
\hline L01XE02 & GEFITINIB & Non regulated \\
\hline L01XE05 & SORAFENIB & Regulated \\
\hline L01XE06 & DASATINIB & Regulated \\
\hline L01XE07 & LAPATINIB & Regulated \\
\hline L01XE08 & NILOTINIB & Regulated \\
\hline L01XE09 & TEMSIROLIMUS & Regulated \\
\hline L01XE11 & PAZOPANIB & Regulated \\
\hline L01XX04 & SUNITINIB & Regulated \\
\hline L01XX28 & IMATINIB & Regulated \\
\hline L01XX34 & ERLOTINIB & Regulated \\
\hline L03AB07 & INTERFERON BETA-1A & Regulated \\
\hline L03AB08 & INTERFERON BETA-1B & Regulated \\
\hline L04AA04 & $\begin{array}{l}\text { ANTITIMOCITO IMMUNOGLOBULINA } \\
\text { (CONEJO) }\end{array}$ & Regulated \\
\hline L04AA06 & MICOFENOLICO ÁACIDO & Regulated \\
\hline L04AA10 & SIROLIMUS & Regulated \\
\hline L04AA13 & LEFLUNOMIDE & Regulated \\
\hline L04AA18 & EVEROLIMUS & Regulated \\
\hline L04AA23 & NATALIZUMAB & Regulated \\
\hline L04AA24 & ABATACEPT & Regulated \\
\hline L04AA27 & FINGOLIMOD & Regulated \\
\hline L04AB01 & ETANERCEPT & Regulated \\
\hline L04AB02 & INFLIXIMAB & Regulated \\
\hline L04AB04 & ADALIMUMAB & Regulated \\
\hline L04AC07 & TOCILIZUMAB & Regulated \\
\hline M05BA04 & ALENDRONICO ÁACIDO & Regulated \\
\hline M05BA07 & RISEDRONICO ÁACIDO & Non regulated \\
\hline M05BA08 & ZOLEDRONICO ACIDO & Regulated \\
\hline N02BE01 & PARACETAMOL & Regulated \\
\hline N03AX09 & LAMOTRIGINA & Regulated \\
\hline N03AX12 & GABAPENTIN & Regulated \\
\hline N03AX14 & LEVETIRACETAM & Regulated \\
\hline N03AX16 & PREGABALINA & Regulated \\
\hline N05AH04 & QUETIAPINA & Regulated \\
\hline N05AN01 & LITIO & Regulated \\
\hline N05AX08 & RISPERIDONA & Regulated \\
\hline R03BA02 & BUDESONIDA & Non regulated \\
\hline R03DC03 & MONTELUKAST & Regulated \\
\hline S01EC03 & DORZOLAMIDA & Non regulated \\
\hline $\begin{array}{r}\mathrm{S} 01 \mathrm{ECO} 3 / / \\
\text { S01ED01 }\end{array}$ & DORZOLAMIDA/TIMOLOL & Regulated \\
\hline $\begin{array}{r}\text { S01EC03// } \\
\text { S01ED51 }\end{array}$ & $\begin{array}{l}\text { DORZOLAMIDA//TIMOLOL COMBI- } \\
\text { NACIONES }\end{array}$ & Non regulated \\
\hline
\end{tabular}


around: new technologies entering the market are usually highly-priced.

\section{Main results}

Despite direct price caps implemented in 2011, total NoPOS drug expenditure grew significantly during 20122015. Total sales grew at a nominal annual rate of $23 \%$, going from $\$ 538 \mathrm{~m}$ in 2011 to $\$ 1224 \mathrm{~m}$ in 2015 in US constant dollars (see Fig. 1). Total expenditure in the institutional market showed a similar pattern.

During the same period, prices decreased systematically until early 2014 (see Fig. 2). In the months after the first updating of the benefit package (POS), prices decreased about $43 \%$. Later, after the IRP method was introduced in mid-2013, prices decreased at a faster rate until the second updating of the POS. In contrast, real pharmaceutical expenditure (quantities proxy) dramatically increased. In a 4-year period, quantities sold in the market doubled.

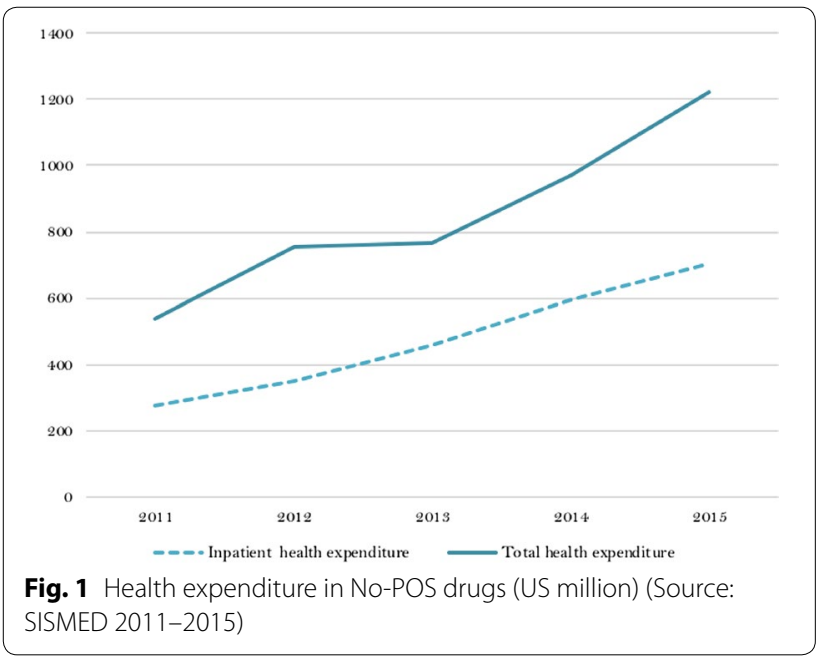

The price index for regulated and non-regulated ATCs was also estimated. Figure 3 shows that the price index of regulated ATCs decreased 44\% between 2012 and 2015, while that of non-regulated ATCs decreased $20 \%$ during the same period. Quantities sold increased in both groups. Quantities of regulated ATCs rose steadily. Nonregulated ATCs were more volatile.

The price index by therapeutic groups exhibit different patterns. For immunosuppressive ATCs, prices decreased $10 \%$ after the first POS update, and levelled off after the second. Units sold increased sharply during the whole period, 2011-2015 (see Fig. 4). All ATC included in this therapeutic group were subjected to a direct control price. In contrast, for insulins, prices increased around $60 \%$ until the second POS update. After this point, prices started to slightly decrease. Quantities sold did not increase in the period. This behaviour may be because this therapeutic class includes both regulated and nonregulated ATC.

\section{Discussion}

Our descriptive analysis shows that, after price control measures were put in place, drug prices decrease about $43 \%$, while real pharmaceutical health expenditure almost doubled. Similar results were obtained for therapeutic groups in which all ATC were regulated. However, if a therapeutic group includes regulated and non-regulated ATCs, results differed substantially. Overall, price control measures did not translate into lower No-POS expenditure. They likely induced an excess of demand.

The observed effect of ERP on prices is consistent with the extant literature on ERP in developed countries. In fact, most studies find a decrease in prices of regulated or new technologies $[18,25,26]$. However, the observed effect on pharmaceutical expenditure contrasts with some studies that report a decrease in pharmaceutical expenditure as a result of ERP [27].
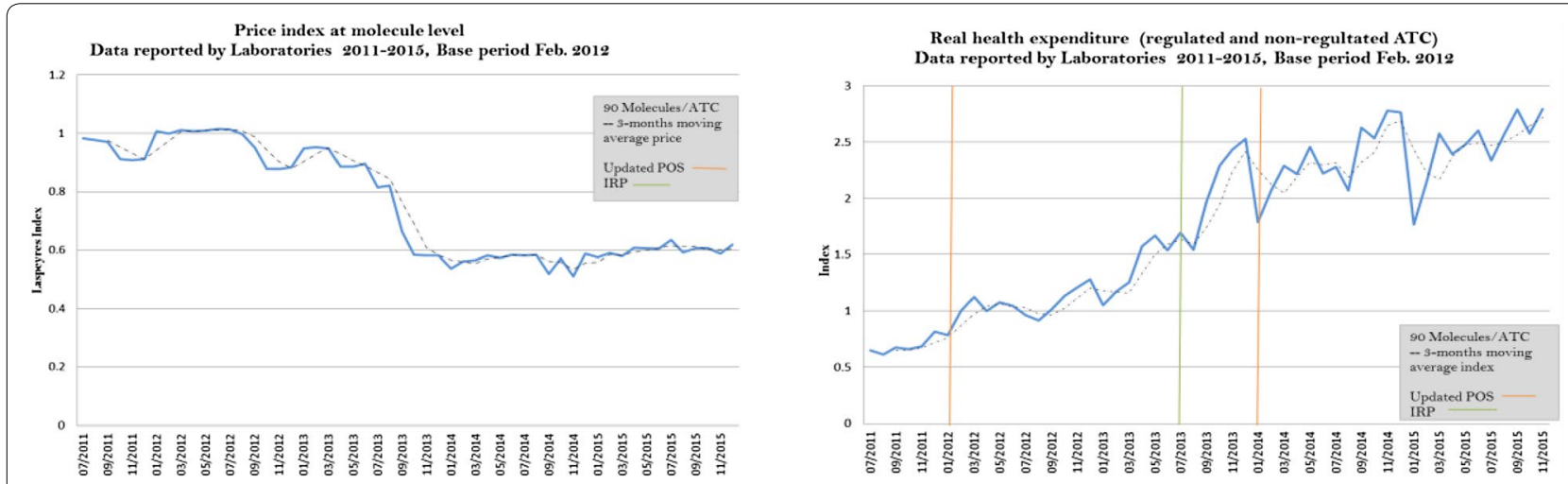

Fig. 2 Price index and real health expenditure for regulated and non-regulated drugs (Source: Data are from July 2011 to December 2015, SISMED 2011-2015. Author's estimations) 

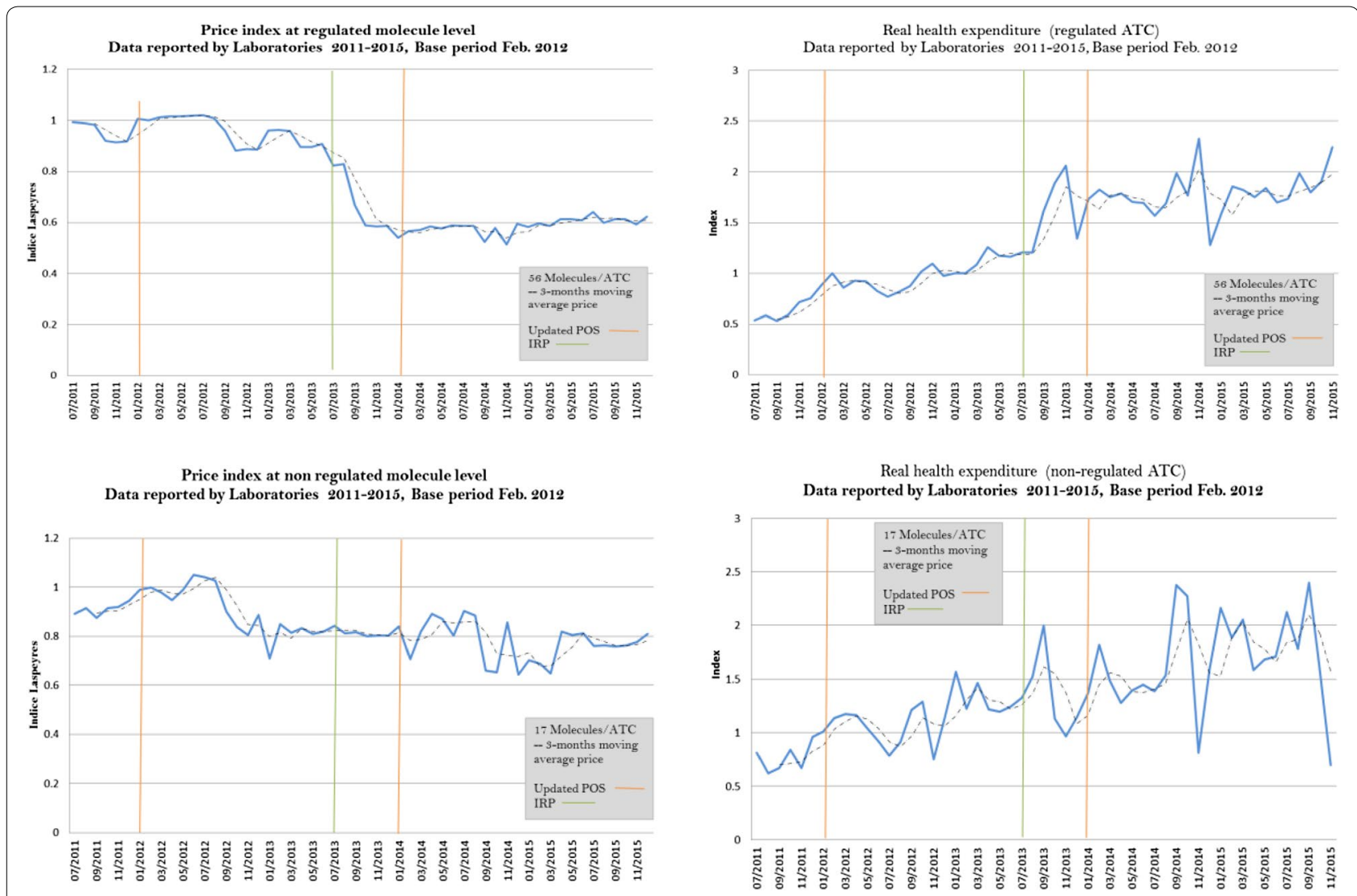

Fig. 3 Price index and real health expenditure for regulated versus non-regulated drugs (Source: Data are from July 2011 to December 2015 , SISMED 2011-2015)

The rapid increase in No-POS drugs expenditure motivated the Colombian government to adopt an aggressive price control strategy. The market response was a disproportionate increase in units sold. A part of such increase can be attributed to better access to drugs due to lower prices, and another part to an increase in marketing efforts by buyers. There is no data to tease apart these two purported effects.

Control policies reduce medicine prices. For the case of Colombia, Romero found that including a drug in the benefit package (POS) reduced its price by $14 \%$ and that introducing IPR reduced its price by $26 \%$ [19]. However, the effects upon total pharmaceutical expenditure are ambiguous. Among OECD countries, maximum price, IPR and health technologies reimbursement mechanism regulations were not found to be associated with cost containment of national health expenditures [28]. Evidence shows that pharmaceutical companies often diversify their portfolios into regulated markets and unregulated markets [21]. In addition, greater use of prescription drugs, replacement of older, cheaper drugs with new and more expensive ones, and the ever higher prices of retail prescription drugs also contribute to increase health expenditure [22].

Our study is limited in several ways. First the decomposition cannot be interpreted as a causal effect. Second, currently data is not audited (reporting is mandatory and a false report could bring serious fines). Third, even without the intention of reporting false data, typos and mistakes may still go undetected.

\section{Conclusions}

The Colombian experience clearly shows that price controls do not necessarily decrease overall real pharmaceutical expenditures. Pharmaceutical expenditure is determined by variation in prices and quantities. ${ }^{2}$ A drug price regulation that does not consider a set of measures to strictly monitor (and eventually investigate and further

\footnotetext{
${ }^{2}$ Pharmaceutical expenditure is also determined by the structure of the market; that is, the share of generics for an active ingredient. Although we did not observe this variable in the paper it is worth acknowledging its importance.
} 


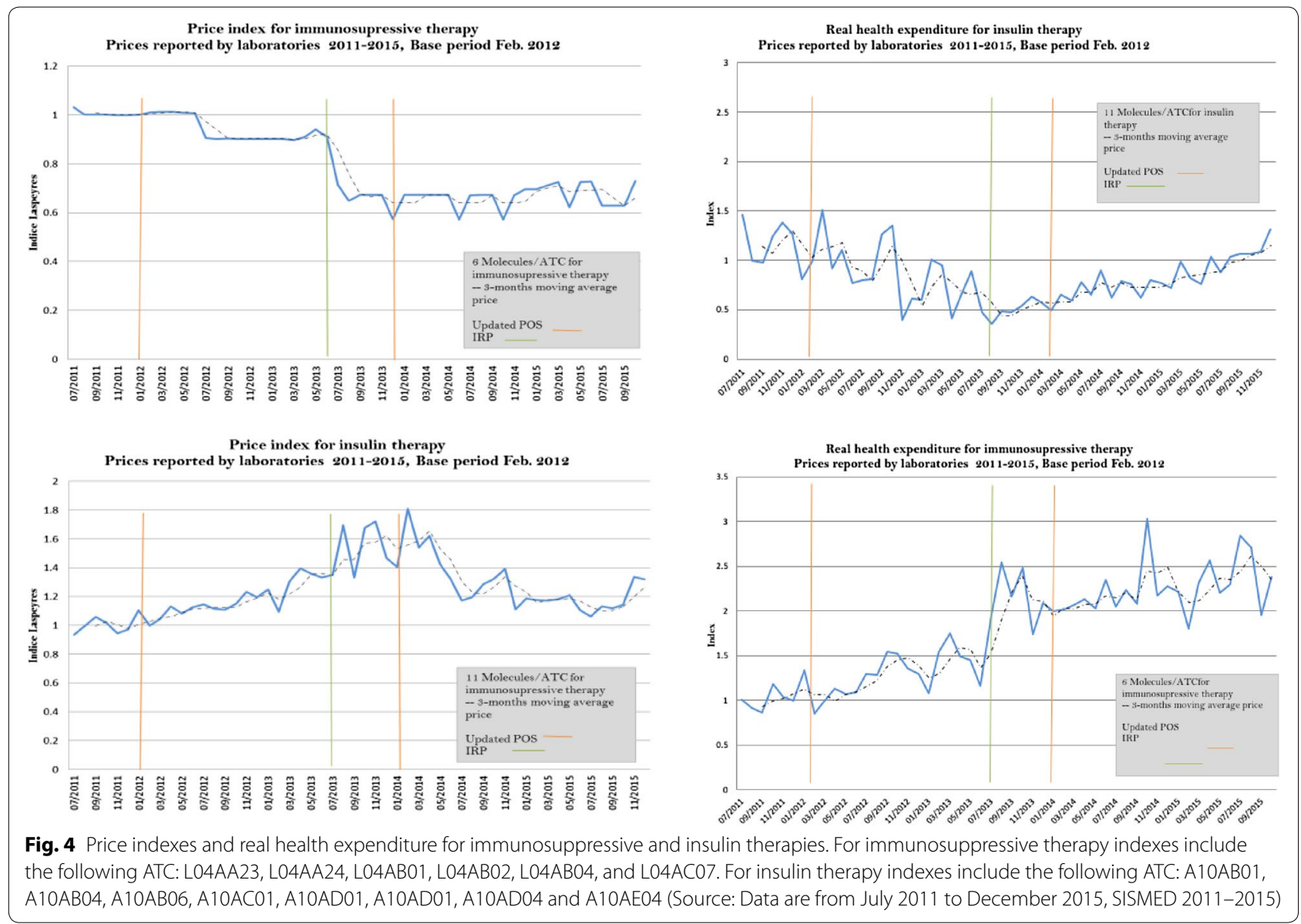

control) quantities sold, is likely to fail in its objective of halting expenditure.

This is a crucial finding in the context of middle income countries like Colombia that still face challenges to guarantee financially sustainable universal healthcare coverage. While ERP may lower pharmaceutical prices, it may also spur an increase in the demand of regulated products, defying the cost control objective that motivated price regulation in the first place.

Increased demand of pharmaceutical products may be a positive thing, as long as the increase is the result of greater access to effective medicines rather than the result of induced demand by pharmaceutical producers. This is an important caveat in the context of middleincome countries where cost-effectiveness analyses and benefit package definition are relatively new, and not always legitimate, policy instruments.

\section{Authors' contributions}

SP and VS analysed, interpreted data, and were major contributors in writing the manuscript. TA, CV, AM and SM contributed analysing and interpreting the results. TA, CV, AM and AG helped editing the manuscript. AM and SM performed the data mining and constructed the databases for analysis. All authors read and approved the final manuscript.

\begin{abstract}
Author details
${ }^{1}$ Centro PROESA, Universidad Icesi, Calle 18 No. 122-135, Cali, Colombia. ${ }^{2}$ Facultad de Ciencias Sociales, Universidad de los Andes, Carrera 1 \# 18A-12, Bogotá, Colombia. ${ }^{3}$ Centro de Pensamiento Medicamentos, Información y Poder, Facultad de Ciencias/Departamento de Farmacia, Universidad Nacional, Bogotá, Colombia. ${ }^{4}$ Ministerio de Salud y Protección Social, Carrera 13 \# 32-76, Bogotá, Colombia.
\end{abstract}

\section{Acknowledgements}

We would like to thank Camila Franco and Johan Loaiza for their input and valuable comments to this manuscript.

\section{Competing interests}

Some of the authors, Alejandro Gaviria, Tatiana S. Andia, Claudia P. Vaca, Alvaro A. Morales and Sergio R. Marquez worked for the Colombian Ministry of Health designing and implementing the pharmaceutical price regulation policy.

\section{Availability of data and materials}

The datasets analysed during the current study are available from the corresponding author on reasonable request.

\section{Consent for publication}

Not applicable.

\section{Ethics approval and consent to participate}

Not applicable.

\section{Funding}

Not applicable. 


\section{Publisher's Note}

Springer Nature remains neutral with regard to jurisdictional claims in published maps and institutional affiliations.

Received: 24 September 2017 Accepted: 13 February 2018

Published online: 02 March 2018

\section{References}

1. Giedion U, Bitrán R, Tristao I, En C, Fuente Proporcionada Por L, Biblioteca $L$, et al. Planes de Beneficios en Salud de Ameérica Latina. Health Benefit Plans in Latin America (Spanish: Planes de beneficios en salud de América Latina). 2014

2. Congress of the Republic of Colombia. Law 100, art. 162. 1993.

3. Rovira J, De Barcelona U, De Catalunya G. The role of prices in drug expenditure analysis. Eur J Helath Econ. 2001:2:142-9.

4. Zapata JG, Nuñez J. La Sostenibilidad Financiera del Sistema de Salud Colombiano. Fedesarrollo. 2012.p. 1-32.

5. Salazar N. El régimen de seguridad social en salud: problemas financieros, medidas adoptadas y retos para el futuro próximo. Notas Fisc Minist Hacienda y Crédio Público. 2011;6

6. Gaviria A. Cost of progress prices of new medicines threaten Colombia's health reform. vol. 105. 2014

7. Romero M. Financial incentives and pharmaceutical prices: The Colombian case. Department of Economics at UC San Diego; 2013. http://econweb.ucsd.edu/ mtromero/pdfs/papers/CompetitionPharma.pdf

8. Ministerio de Salud y Protección Social. Recobros al FOSYGA por tecnologías en salud no incluidas en el plan de beneficios 2009-2014. Cifras Financieras del Sector Salud: Boletín trimestral No. 11:2015.

9. Health M of. Agreement 029. 2011

10. Vacca C, Acosta A, Rodriguez I. Precios de Referencia Internacional y Análisis de Costo Minimización para la Regulación de Precios de Medicamentos en Colombia. Value Health. 2011:14(5 SUPPL):S16-9.

11. Health Regulatory Commission. Circular 03. 2013.

12. Health Regulatory Commission. Circular 01. 2014

13. Health Regulatory Commission. Circular 04. 2013.
14. Health Regulatory Commission. Circular 05. 2013.

15. Health Regulatory Commission. Circular 07. 2013.

16. Ministerio de Salud y Protección Social. Recobros al Fosyga por tecnologias en salud no incluidas en el plan de beneficios 2009-2014. Cifras Financ del Sect la salud. 2015; Julio-Agos.

17. Comisión Nacional de Precios de Medicamentos y Dispositivos Medicos. 2011.

18. Leopold C, Mantel-Teeuwisse AK, Seyfang L, Vogler S, de Joncheere K, Laing $\mathrm{RO}$, et al. Impact of external price referencing on medicine pricesa price comparison among 14 European countries. South Med Rev. 2012:5(2):34

19. Rémuzat C, Urbinati D, Mzoughi O, El Hammi E, Belgaied W, Toumi M. Overview of external reference pricing systems in Europe. J Mark Access Health Policy. 2015;3.

20. Ruggeri K, Nolte E. Pharmaceutical pricing: the use of external reference pricing. Cambridge: RAND Corporation; 2013.

21. Organisation for Economic Co-operation and Development. Pharmaceutical pricing policies in a global market. Organisation for Economic Co-operation and Development; 2008

22. Kaló Z, Alabbadi I, Al Ahdab OG, Alowayesh M, Elmahdawy M, Al-Saggabi $\mathrm{AH}$, et al. Implications of external price referencing of pharmaceuticals in Middle $\{$ East countries. Expert Rev Pharmacoecon Outcomes Res. 2015;15(6):993-8

23. Nguyen TA, Knight R, Roughead EE, Brooks G, Mant A. Policy options for pharmaceutical pricing and purchasing: issues for low- and middleincome countries. Health Policy Plan. 2014;30(2):267-80.

24. Brekke KR, Holmas TH, Straume OR. Reference pricing, competition, and pharmaceutical expenditures: theory and evidence from a natural experiment. J Public Econ. 2011:95(7):624-38.

25. Håkonsen H, Horn AM, Toverud E-L. Price control as a strategy for pharmaceutical cost containment - $\{$ What $\}$ has been achieved in Norway in the period 1994-2004. Health Policy. 2009;90(2):277-85.

26. Windmeijer F, De Laat E, Douven R, Mot E. Pharmaceutical promotion and GP prescription behaviour. Health Econ. 2006;15(1):5-18.

27. Filko M, Szilagyiova P. The Slovak experience in the international price benchmarking for prescription drugs. Value Health. 2009;12(7):229-30.

28. Ben-Aharon O, Shavit O, Magnezi R. Does drug price-regulation affect healthcare expenditures? Eur J Health Econ. 2017;18(7):859.

\section{Submit your next manuscript to BioMed Central and we will help you at every step:}

- We accept pre-submission inquiries

- Our selector tool helps you to find the most relevant journal

- We provide round the clock customer support

- Convenient online submission

- Thorough peer review

- Inclusion in PubMed and all major indexing services

- Maximum visibility for your research

Submit your manuscript at www.biomedcentral.com/submit
C) Biomed Central 